DOI 10.18551/rjoas.2021-10.33

\title{
IDENTIFICATION AND CHARACTERIZATION OF BIOSURFACTANT PRODUCING BACTERIA ISOLATED FROM DIESEL-CONTAMINATED SEAWATER
}

\author{
Susanti Marlinda Elvina* \\ Master's Study Program, Department of Aquaculture, Faculty of Fisheries and \\ Marine Science, University of Brawijaya, Indonesia \\ Maftuch \\ Department of Aquaculture, Faculty of Fisheries and Marine Science, \\ University of Brawijaya, Indonesia
}

\section{Asep Awaludin Prihanto}

Department of Fishery Product Technology, Faculty of Fisheries and Marine Science, University of Brawijaya, Indonesia

*E-mail: marlindaelvina@gmail.com

\begin{abstract}
One of the most severe environmental problems today is oil pollution, especially in seawater. Bioremediation is one method to restore the environment due to the pollution of hydrocarbon compounds. Natural surfactants produced by bacteria can accelerate the biodegradation of hydrocarbon compounds. This study aims to obtain indigenous bacteria which produce biosurfactants from the Tanjung Perak Port, Indonesia. Isolation using selective media obtained 22 isolates of bacteria. The results of the screening of biosurfactant-producing bacteria used three different tests. There are the drop collapse test, oil spreading test, and emulsification test. MWN-8 isolate was the isolate that showed the best results. Microbact testing confirmed that the MWN-8 isolate was Aeromonas hydrophila with an accuracy rate of $96.43 \%$.
\end{abstract}

\section{KEY WORDS}

Aeromonas hydrophila, bioremediation, biosurfactant, oil spills.

The increasing exploration, exploitation, and transportation activities using petroleum hydrocarbon have made it more needed in recent years. However, the utilization of petroleum hydrocarbon triggers environmental problems, such as oil spills[1].The total volume of oil spills in the world's ocean has reached 1,000 tons per year. During the last two decades, there have been 37 oil spills cases that occurred in Indonesia. The most famous case occurred in Balikpapan Bay, which spilled about 5,600 tons of oil and caused damage to marine and coastal ecosystems [2].

The oil pollution cases in Indonesia occur due to sea transportation activities. Shipping lanes or ship traffic, especially the traffic of tankers, passenger ships, and cargo ships, make the waters in the port area potentially experience oil pollution[3]. In addition, ship refueling activities in the port area also contribute to oil pollution. A place that is prone to oil pollution is Tanjung Perak Port. Tanjung Perak Port is the second largest port in Indonesia. Spectral data from the Terra ASTER satellite detects the largest concentration of oil content in seawater around Tanjung Perak Port is came from the shipping lane towards the Tanjung Perak port. This is caused by loading and unloading activities of ships and tankers' deballasting activities [4]. The potential of this oil pollution problem needs to be addressed immediately.

The utilization of technology to overcome the problem of oil pollution is a very appropriate approach. Currently, the technology used includes physical, chemical, and biological methods. Biological methods are natural, so the impact on humans and the environment is more negligible. Another advantage of this method is more economical, and 
it's not causingany secondary pollutants. Some bioremediation agents that are often used are bacteria, yeast, plants, and algae. Hydrocarbonoclastic bacteria are a group of microorganisms that are dominant in degrading hydrocarbons in the environment. With their metabolic ability, Indigenous bacteria play an important role in oil bioremediation because they are welladapted to their environment[5]. These bacteria can produce environmentally friendly secondary metabolite products called biosurfactants.

Biosurfactants can act as emulsifying agents by lowering the surface tension and forming micelles. There have been many studies on synthetic chemical surfactants to increase the solubility of certain hydrocarbons. The disadvantage of chemical surfactants is that they are not biodegradable, causing high toxicity to aquatic biota, hydrocarbondegrading bacteria, and the environment. In addition, chemical surfactants can also inhibit the biodegradation process[6].Bioremediation techniques using bacteria and biosurfactants to prevent oil spills in coastal areas have not been widely used. Limited data and in-depth studies are still needed to be done. This study was aimed to obtain isolates of indigenous bacteria producing biosurfactants from Tanjung Perak Port Seawater.

\section{MATERIALS AND METHODS OF RESEARCH}

Water samples were collected from two different locations in the Tanjung Perak Port area. Site 1 is located at $7^{\circ} 20^{\prime} 81,65^{\prime \prime}$ south latitude and $112^{\circ} 72^{\prime} 14,03^{\prime \prime}$ east longitude while site two is located at $7^{\circ} 19^{\prime} 97,60^{\prime \prime}$ south latitude and $112^{\circ} 73^{\prime} 18,42^{\prime \prime}$ east longitude (Fig 1). The sampling method in this study used the purposive sampling method. $1000 \mathrm{~mL}$ of seawater samples were taken from each site using sterile bottles and stored in a ${ }^{\circ} \mathrm{C}$ icebox for analysis in the laboratory. In addition, water quality supporting parameters (temperature, $\mathrm{pH}$, salinity, and oil content) were analyzed [7].

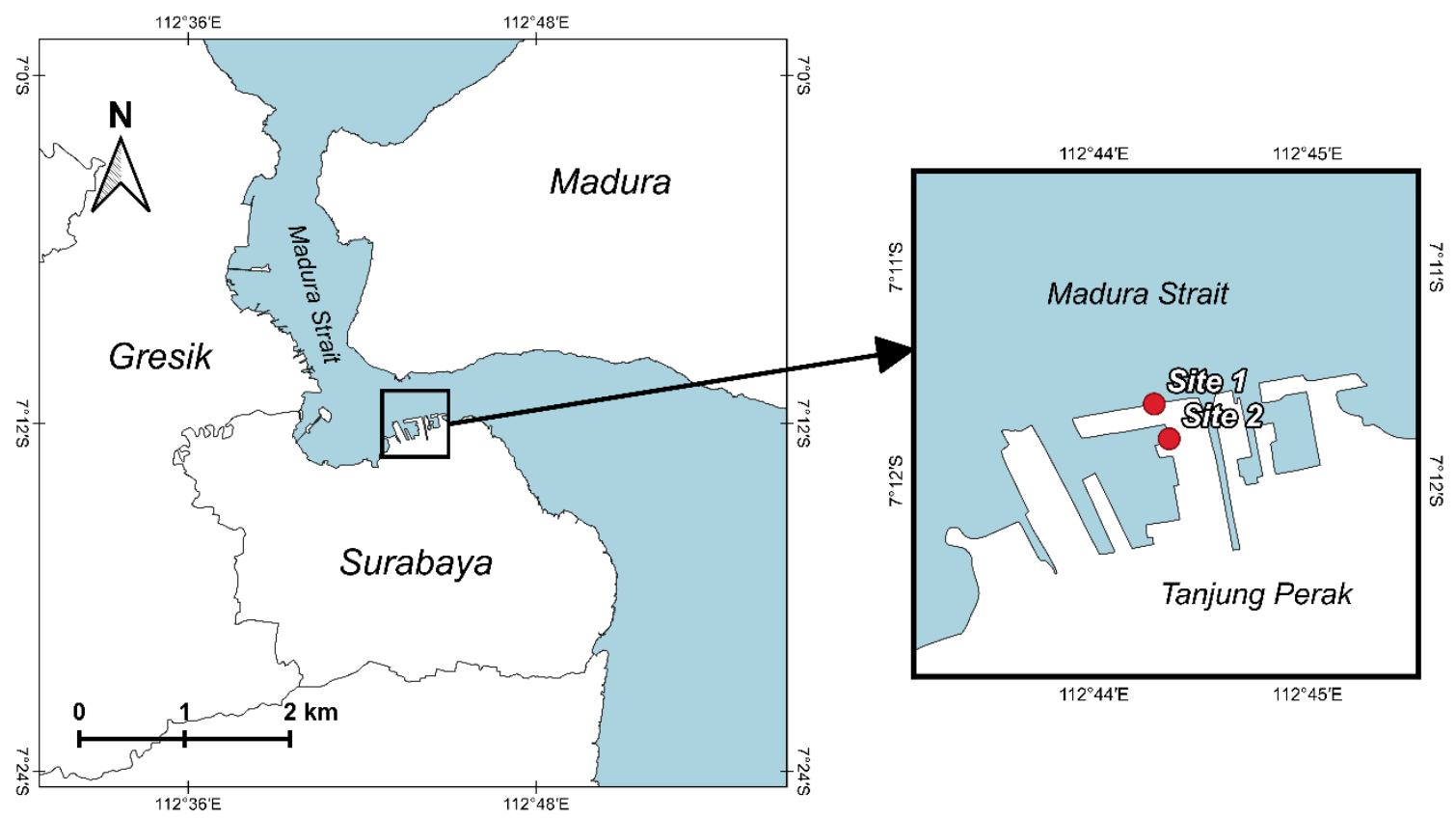

Figure 1 - Sampling Location at Tanjung Perak Port

Isolation and Morphological Characterization of Bacteria Colony. The water sample was diluted to $10^{-5}$ using $0.85 \%$ sodium chloride solution. $0.1 \mathrm{~mL}$ water sample from $10^{-5}$ dilution was cultured in Nutrient Agar (NA) medium $+1 \%$ diesel oil (as carbon source) by spread plate method. The samples were then incubated for $24-48$ hours at $30^{\circ} \mathrm{C}[8]$. After the incubation process, the bacterial colonies were visually observed.

The morphology of bacterial colonies was observed macroscopically from the shape, color, elevation, and margins. The different colonies were then taken and transferred for 
microscopic characterization. The reference used in this morphological characterization process was determined based on Harley-Prescott [9]. Selected colonies were purified and stored as stock cultures.

Screening of Biosurfactant Producing Isolates:

Drop collapse test, a total of two $\mu$ diesel oil was dropped on the surface of the parafilm. Above the droplet, five $\mu \mathrm{l}$ of bacterial supernatant was added. After 1 minute of observation, the shape of the droplets was observed. If the droplet is flat, the isolate containsa biosurfactant, and the isolate was given a positive score. On the other hand, if the droplets remained round, the score was negative because they did not contain biosurfactants. These results were compared with the control treatment using distilled water[10].

Oil spreading test, a total of $50 \mu \mathrm{L}$ diesel oil was dropped into a petri dish containing 50 $\mathrm{ml}$ of distilled water. Then ten $\mu \mathrm{L}$ bacterial supernatant from each isolate was added to the surface of the diesel oil. If the isolate contains biosurfactants, a clear zone will be formed. The clear zone formed was measured and scored based on [11].

Emulsification Index (E24). In this test, the bacterial supernatant of each isolate was mixed with diesel oil. The sample was carried out in a test tube with a ratio of $1: 1(1.5 \mathrm{ml}$ of supernatant and $1.5 \mathrm{ml}$ of diesel oil). A mixture of diesel oil and distilled water was used as a control treatment. Then the sample was vortexed at high speed for 2 minutes and left for 24 hours to form a stable emulsion. Emulsification test results are expressed as emulsification index. The percentage of the emulsification index is calculated according to the formula below [12].

$$
E_{24}(\%)=\frac{H E}{H T} \times 100
$$

Where: HE - the height of emulsion layer $(\mathrm{cm})$; HT - total height of liquid column $(\mathrm{cm})$.

Identification of Biosurfactant Producing Bacteria. The bacteria identification in this study using the Microbact Test [13]. The working principle of this test is by reacting the isolate suspension into 12 types of wells that already contain a carbon source and other biochemical compounds. Testing for gram-positive bacteria uses GNB 12B by ignoring GNB 12A. Testing for gram-negative bacteria uses 1 set of GNB 12A/B/E 24E. The first procedure for using microbact is to perform an oxidation test. This test is carried out to determine the type of microbact system used. One ose of bacterial isolate to be identified was taken and then placed on oxidase paper (Bactident Oxidase Kit). Then observed the color changes in 60 seconds, purple color indicates positive oxidase. Microbact MB-12A + MB-12B or microbact 24E were used for positive oxidase results. If it is colorless, it shows negative oxidation and uses MB-12A microbact.

\section{RESULTS AND DISCUSSION}

The results of the measurement of water quality parameters are shown in Table 1.

Table 1 - Water Quality Analysis

\begin{tabular}{llllll}
\hline No & Parameter & Method & Site 1 & Site 2 & Mean \pm SD \\
\hline 1. & Temperature $\left({ }^{\circ} \mathrm{C}\right)$ & (Baird et al., 2017) [7] & 31.4 & 31.3 & $31.35 \pm 0.07$ \\
2. & pH & (Baird et al., 2017) [7] & 6.58 & 6.55 & $6.57 \pm 0.02$ \\
3. & Salinity $(\mathrm{ppt})$ & (Baird et al., 2017) [7] & 26.2 & 26.6 & $26.4 \pm 0.28$ \\
4. & Oil Content $(\mathrm{mg} / \mathrm{L})$ & (Baird et al., 2017) [7] & 2.0 & 2.0 & $2 \pm 0.0$ \\
\hline
\end{tabular}

The temperature range of sea waters in the Tanjung Perak Port area is $31.35 \pm 0.07$ ${ }^{\circ} \mathrm{C}, \mathrm{pH}$ is $6.57 \pm 0.02$, salinity is $26.4 \pm 0.28 \mathrm{ppt}$, and oil concentration is $2 \mathrm{mg} / \mathrm{L}$. These results indicate that the waters of Tanjung Perak Port still fulfill the standard of port water quality[14]. The oil content in the area is still relatively high, so it is not suitable for marine biota that lives in this area. However, the high oil concentration in this area can increase the 
number of hydrocarbonoclastic bacteria. These bacteria utilize these carbon compounds as a source of nutrients.

Water quality plays a vital role in controlling the nature and metabolic rate of hydrocarbon bacteria. Hydrocarbonoclastic bacteria are well in degrading oil in the temperature range of $27-32{ }^{\circ} \mathrm{C}$. At the same time, the optimal $\mathrm{pH}$ value for the growth and degradation of oil by bacteria is 7.2. If the $\mathrm{pH}$ value is lower than 5.2 or higher than 8.4, the level of oil degradation will be significantly reduced[15]. From the results of the measurement of salinity, the bacteria that can live in this range are halophilic. Halophilic bacterial species can survive in the presence of high concentrations of $\mathrm{NaCl}$. Halophilic microorganisms contain enzymes that maintain their high salinity, $\mathrm{pH}$, and temperatures [16].From the environmental conditions results, mesophilic bacteria with a neutral $\mathrm{pH}$ that tends to be slightly acidic will be generated.

Isolation and Characterization of Bacteria. In the isolation process, 22 pure isolates were obtained. Furthermore, the bacterial colonies that grew were observed directly, including shape, color, elevation, and margins. Then it was characterized microscopically by Gram staining. The results of morphological characterization can be seen in Table 2.

Table 2 - Morphological Characterization of Isolated Bacteria

\begin{tabular}{|c|c|c|c|c|c|c|}
\hline \multirow[b]{2}{*}{$\begin{array}{l}0 \\
0 \\
0 \\
0 \\
0 \\
\stackrel{0}{0} \\
\underline{0} \\
\underline{0}\end{array}$} & \multicolumn{4}{|c|}{ Macroscopic } & \multicolumn{2}{|c|}{ Microscopic } \\
\hline & $\begin{array}{l}\text { E } \\
\text { 오 }\end{array}$ & 흥 & $\begin{array}{l}\text { 듬 } \\
\frac{\mathbb{J}}{d} \\
\frac{d}{\square}\end{array}$ & $\begin{array}{l}\frac{5}{\overline{0}} \\
\frac{\bar{\sigma}}{\Sigma}\end{array}$ & $\frac{E}{\mathbb{N}}$ & $\begin{array}{l}\frac{0}{\pi} \\
\frac{\widetilde{d}}{\omega}\end{array}$ \\
\hline MWN-1 & Punctiform & Cream & Raised & Undulate & Positive & Cocci \\
\hline MWN-2 & Irregular & Cream & Convex & Undulate & Positive & Rods \\
\hline MWN-3 & Circular & Cream & Convex & Entire & Positive & Rods \\
\hline MWN-4 & Circular & Cream & Raised & Entire & Negative & Rods \\
\hline MWN-5 & Circular & White & Convex & Entire & Negative & Rods \\
\hline MWN-6 & Irregular & Cream & Convex & Entire & Negative & Rods \\
\hline MWN-7 & Irregular & White & Raised & Undulate & Negative & Rods \\
\hline MWN-8 & Circular & Cream & Convex & Entire & Negative & Rods \\
\hline MWN-9 & Irregular & White & Raised & Undulate & Negative & Cocci \\
\hline MWN-10 & Irregular & White & Convex & Undulate & Positive & Rods \\
\hline MWS-1 & Irregular & White & Convex & Undulate & Negative & Rods \\
\hline MWS-2 & Circular & Cream & Raised & Undulate & Negative & Rods \\
\hline MWS-3 & Irregular & White & Convex & Undulate & Negative & Cocci \\
\hline MWS-4 & Circular & Cream & Raised & Undulate & Positive & Rods \\
\hline MWS-5 & Circular & Cream & Raised & Entire & Negative & Rods \\
\hline MWS-6 & Irregular & Cream & Raised & Undulate & Negative & Rods \\
\hline MWS-7 & Irregular & Cream & Raised & Undulate & Negative & Rods \\
\hline MWS-8 & Irregular & White & Convex & Undulate & Negative & Rods \\
\hline MWS-9 & Irregular & Cream & Raised & Entire & Negative & Cocci \\
\hline MWS-10 & Irregular & White & Convex & Undulate & Positive & Rods \\
\hline MWS-11 & Irregular & White & Convex & Undulate & Negative & Rods \\
\hline MWS-12 & Irregular & White & Convex & Undulate & Negative & Rods \\
\hline
\end{tabular}

Note: * MWN: Isolates from site 1; MWS: Isolates from site 2.

Based on the number and morphology of the isolated colonies, there were no significant differences between the two sites. From the above results, it was found that most of the colonies were irregular and circular in shape. There is one colony in the form of punctiform. White and cream-colored were found almost evenly at both sites. The elevation of the 22 isolates showed that the results were dominated by the convex and undulate form of the margin. The cell shape of all isolates was dominated by rod bacterial. The percentage of isolates of gram-negative bacteria (72.7\%) compared to gram-positive bacteria (27.3\%).

The study on the characterization of isolated bacteria from the Jakarta Port seawater showed the same result. The presence of gram-negative bacteria was more dominant. The lipid structure of the negative bacterial cell wall facilitates the absorption of nutrients present 
in the oil-contaminated environment. This causes gram-negative bacteria to dominate in the bacterial community in the environment [17].

Screening of Biosurfactant. A total of 22 isolates or $100 \%$ of the total isolates obtained were tested for their ability to produce biosurfactants. This capability test is carried out using three methods, there are drop collapse, oil spreading and emulsification test. The screening results can be seen in Table 3 and Figure 2.

Table 3 - Screening of Biosurfactant Producing Bacteria

\begin{tabular}{lcc}
\hline & & Screening of Biosurfaktan \\
\hline Control & Drop Collapse Test & Oil Spreading Test \\
MWN-1 & - & - \\
MWN-2 & + & ++ \\
MWN-3 & + & ++++ \\
MWN-4 & + & +++ \\
MWN-5 & + & +++ \\
MWN-6 & ++ & +++ \\
MWN-7 & + & +++ \\
MWN-8 & + & ++ \\
MWN-9 & ++ & ++++ \\
MWN-10 & + & +++ \\
MWS-1 & + & + \\
MWS-2 & + & ++ \\
MWS-3 & + & ++ \\
MWS-4 & + & ++ \\
MWS-5 & ++ & ++ \\
MWS-6 & ++ & ++ \\
MWS-7 & ++ & ++++ \\
MWS-8 & + & ++ \\
MWS-9 & ++ & ++++ \\
MWS-10 & + & ++ \\
MWS-11 & + & ++ \\
MWS-12 & ++ & +++ \\
MOt & ++ & ++ \\
\hline
\end{tabular}

Note: *Drop collapse test (DCT): (-) completely spherical, (+) slightly flat, and (++) flat; **Oil spreading test (OST) based on the diameter of the clear zone: (-) no diameter, (+) diameter $\leq 10 \mathrm{~mm},(++)$ diameter 10-30 mm, $(+++)$ diameter $30-50 \mathrm{~mm}$ and $(++++)$ diameter $\geq 50 \mathrm{~mm}$.

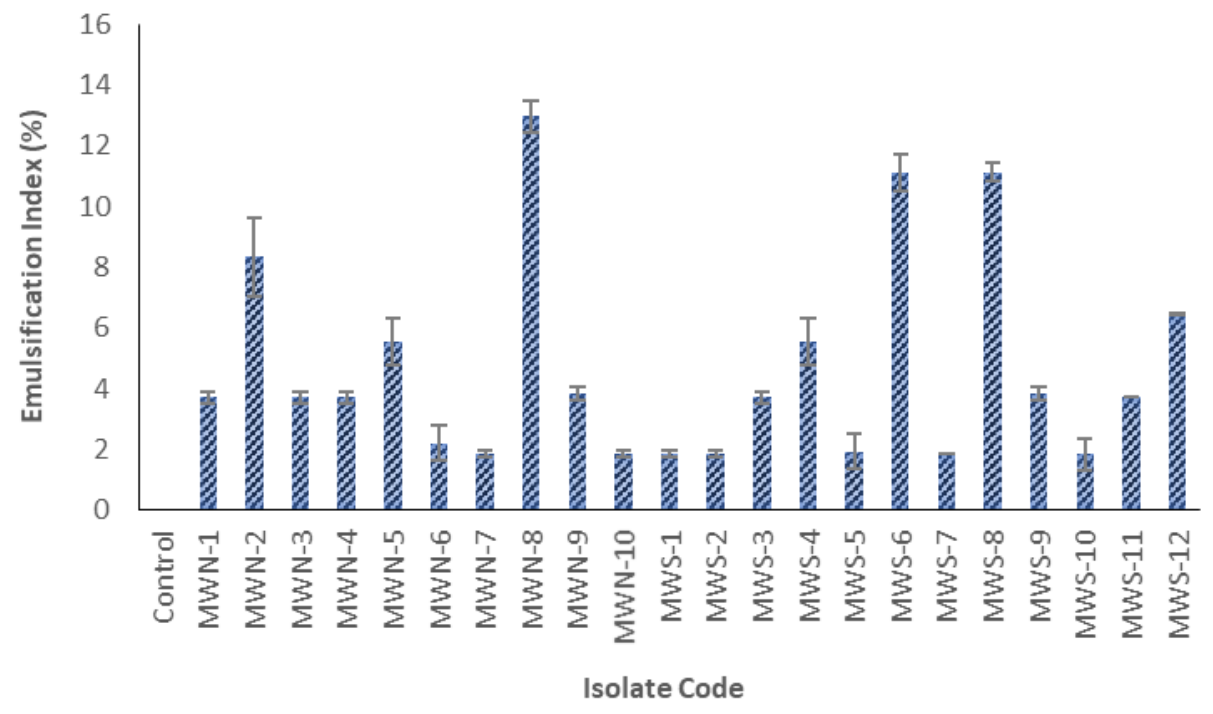

Figure 2 - Emulsification Index $\left(\mathrm{E}_{24}\right)$. Error bars indicate standard deviation

The positive results in the drop collapse test were obtained in all isolates. The highest positive scores were shown by isolates MWN-5, MWN-8, MWS-4, MWS-5, MWS-6, MWS-8, MWS-11, and MWS-12. The positive results shown by the flat-shaped droplets on the 8 
isolates were due to the decreased interfacial tension between the sample and the oil. The control treatment showed negative results with a round and stable shape. This is due to the polar nature of water molecules, which will attract the water surface from the hydrophobic surface of the oil [18]. So from the results of this test, 22 isolates have the potential to produce biosurfactants.

The diameter of the clear zone in the oil spreading test ranges from 9.6 to $53.6 \mathrm{~mm}$. Isolate MWN-2, MWN-8, MWS-6, and MWS 8 produced the largest clear zone diameter from the total isolates found. The clear zone formed as a result of the addition of bacterial isolates into the test media so that there is bacterial activity to utilize carbon sources in producing biosurfactants. In contrast to the control treatment, which showed no clear zone formed[19].

The emulsification test results obtained in this study ranged from 1.85 to $12.96 \%$. The emulsification test showed that isolates MWN-2, MWN-8, MWS-6, and MWS-9 had higher scores than 18 other bacterial isolates. The results of the emulsification test were MWN-2 (8.3\%), MWN-8 (12.96\%), MWS-6 (11.11\%), and MWS-8 (11.11\%). The emulsification of diesel oil in the growth medium showed the production of biosurfactants by the bacteria[20].

The results of the three screening tests showed that all isolates that were positive in the drop collapse test also showed positive results in the oil spreading test. In addition, it was confirmed that the results of the emulsification test screening showed the same results. Of all isolates producing biosurfactants, the MWN-8 isolate was able to produce biosurfactants with the highest emulsification index value of $12.96 \%$. Then the identification of the best bacteria as a result of the biosurfactant screening tests was carried out.

Identification of Biosurfactant Producing Bacteria. The identification results using the Microbact test shows that the MWN-8 bacterial isolate was a species of Aeromonas hydrophila with an accuracy rate of $96.43 \%$. In detail, the results of biochemical testing using microbact can be seen in Figure 3.

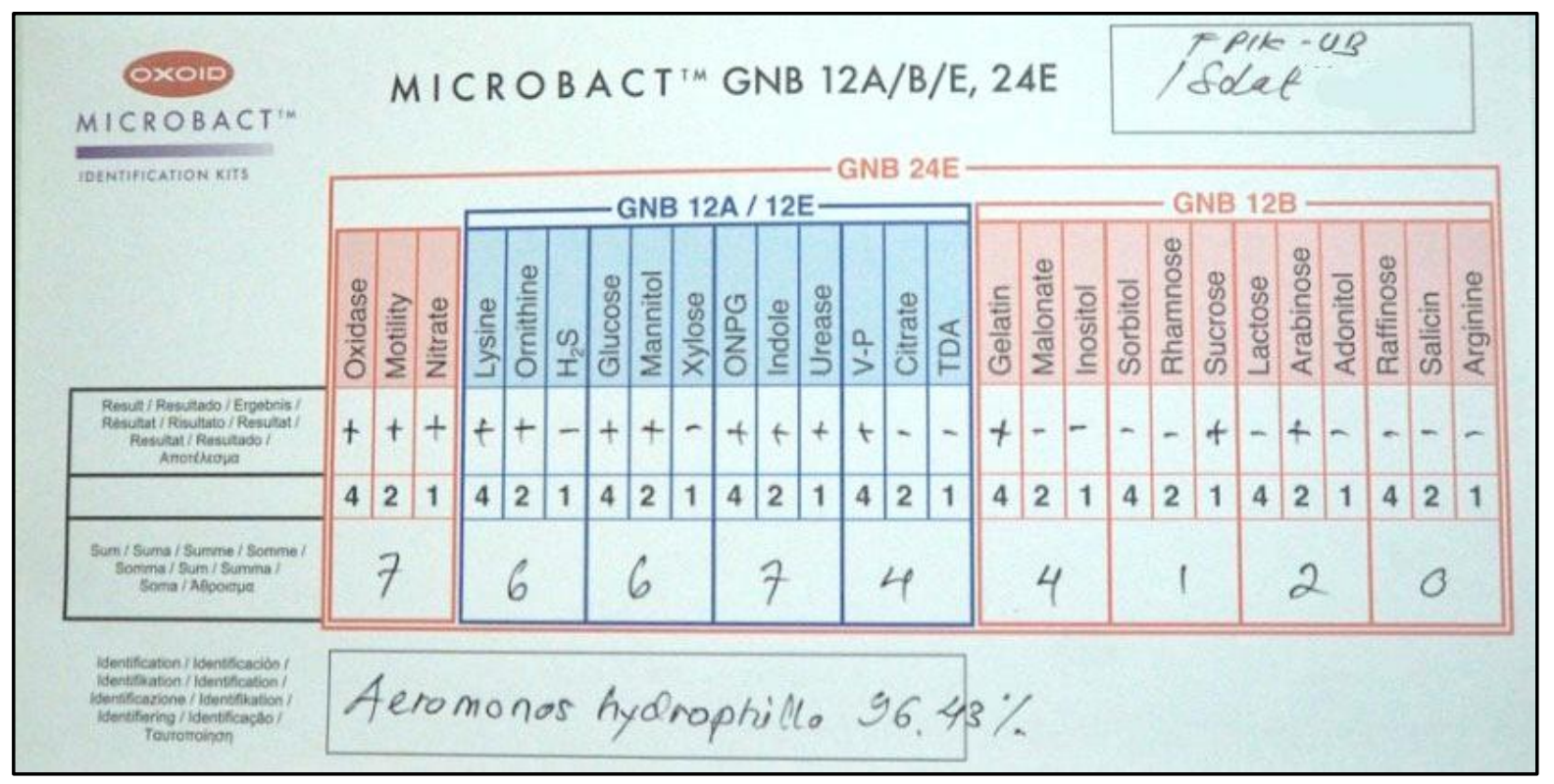

Figure 3 - Identification of isolate MWN-8 using Microbact

A. hydrophilais able to live in freshwater, brackish, and marine environments because they have high enough osmoregulation ability. The study reported that this bacteria was isolated from the Java Island seawater, which was contaminated with oil [21]. Therefore, a. hydrophila can be a potential candidate for biosurfactant-producing bacteria. The type of biosurfactant produced by Aeromonas sp. Most are glycolipid biosurfactants. Glycolipid biosurfactant obtained from Aeromonas $s p$. isolated from tropical estuary waters. These compounds contain 38\% carbohydrates, unidentified lipids, and do not contain protein, so they are classified as glycolipids [22]. Glycolipids produced by Aeromonas sp. declared capable of emulsifying various hydrocarbon substrates. 


\section{CONCLUSION}

The results of this study confirm that the oil-contaminated area is a potential site for obtaining biosurfactant-producing bacteria. A total of 22 pure isolates obtained from the Tanjung Perak Port seawater showed the ability to produce biosurfactants with different characteristics. Isolates with code MWN-8 were isolates that had the highest ability to produce biosurfactants. The results of the species analysis using the microbact confirmed that the species is Aeromonas hydrophila. Further research on the potential and effectiveness of $A$. hydrophila to degrade diesel oil still needs to be done.

\section{REFERENCES}

1. Yang Y. et al., "Isolation, enhanced growth, and degradation characterization of a strain marine petroleum degrading bacteria," Environ. Technol. Innov., vol. 18, p. 100796, 2020, doi: 10.1016/j.eti.2020.100796.

2. Mustafa I. and L. T. Oktaviani, "Biosurfactant production and diesel-fuel removal by isolated bacteria from Kalimas Estuary, Madura Strait," IOP Conf. Ser. Earth Environ. Sci., vol. 743, no. 1, 2021, doi: 10.1088/1755-1315/743/1/012062.

3. Widhayanti A., A. Ismanto, and B. Yulianto, "Sebaran Tumpahan Minyak Dengan Pendekatan Model Hidrodinamika dan Spill Analysis Di Perairan Cilacap, Jawa," J. Oseanografi, vol. 4, no. 4, pp. 641-650, 2015.

4. Khomsin and D. G. Pratomo, "Deteksi Sebaran Tumpahan Minyak (Oil Spills) Dengan Citra Aster," Geoid, vol. 4, no. 2, pp. 137-142, 2010, doi: 10.12962/j24423998.v4i2.7311.

5. Ueno A., Y. Ito, I. Yumoto, and H. Okuyama, "Isolation and characterization of bacteria from soil contaminated with diesel oil and the possible use of these in autochthonous bioaugmentation," World J. Microbiol. Biotechnol., vol. 23, no. 12, pp. 1739-1745, 2007, doi: 10.1007/s11274-007-9423-6.

6. Mohanty S., J. Jasmine, and S. Mukherji, "Practical considerations and challenges involved in surfactant enhanced bioremediation of oil," Biomed Res. Int., vol. 2013, 2013, doi: 10.1155/2013/328608.

7. Baird R. B., A. D. Eaton, and E. W. Rice, Standard Methods for the Examination of Water and Wastewater, 23rd Editi. American Public Health Associaton, 2017.

8. Titah H. S., "E nvironment A sia," no. July 2016, 2017, doi: 10.14456/ea.2016.21.

9. Prescott $\mathrm{H}$., Laboratory exercises in microbiology. 2002.

10. Almansoory A. F., M. Idris, S. R. S. Abdullah, and N. Anuar, "Screening for potential biosurfactant producing bacteria from hydrocarbon-degrading isolates," Adv. Environ. Biol., vol. 8, no. 3 SPEC. ISSUE, pp. 639-647, 2014.

11. Wu Y., M. Xu, J. Xue, K. Shi, and M. Gu, "Characterization and Enhanced Degradation Potentials of Biosurfactant-Producing Bacteria Isolated from a Marine Environment," ACS Omega, vol. 4, no. 1, pp. 1645-1651, 2019, doi: 10.1021/acsomega.8b02653.

12. Mouafo T. H., A. Mbawala, and R. Ndjouenkeu, "Effect of different carbon sources on biosurfactants' production by three strains of Lactobacillus spp.," Biomed Res. Int., vol. 2018, 2018, doi: 10.1155/2018/5034783.

13. Awaludin Prihanto A., H. Dwi Laksono Timur, A. Abdul Jaziri, R. Nurdiani, and K. A. Pradarameswari, "Isolasi Dan Identifikasi Bakteri Endofit Mangrove Sonneratia Alba Penghasil Enzim Gelatinase Dari Pantai Sendang Biru, Malang, Jawa Timur," Indones. J. Halal, vol. 1, no. 1, p. 31, 2018, doi: 10.14710/halal.v1i1.3114.

14. Pemerintah, "Penyelenggaraan Perlindungan dan Pengelolaan Lingkungan Hidup: Baku Mutu Air Laut," 2021.

15. Gao J. et al., "Isolation and characterization of a high-efficiency marine diesel oildegrading bacterium," Pet. Sci., vol. 18, no. 2, pp. 641-653, 2021, doi: 10.1007/s12182020-00540-z.

16. Di Donato P. et al., "Exploring marine environments for the identification of extremophiles and their enzymes for sustainable and green bioprocesses," Sustain., vol. 11, no. 1, 2018, doi: 10.3390/su11010149. 
17. Alfiansah Y. R., M. Adindasari, M. Argarini, Y. Darmayati, and - Ruyitno, "Isolation and Distribution of Crude Oil and Polycyclic Aromatic Hydrocarbon-Degrading Bacteria From Polluted Harbours in North Jakarta," Mar. Res. Indones., vol. 39, no. 2, pp. 79-85, 2015, doi: 10.14203/mri.v39i2.49.

18. Wibisana A., "Isolasi Dan Skrining Mikroba Penghasil Biosurfaktan Dari Air Laut Yang Tercemar Minyak," J. IIm. Tek. Kim., vol. 2, no. 2, p. 55, 2018, doi: 10.32493/jitk.v2i2.1680.

19. Najiyah D., N. Vita, and C. Nanda, "Manfaat Surfaktan dari Bakteri Laut Hidrokarbonoklastik untuk Akselerator Proses Hidrokarbon Minyak Bumi," Lembaran Publ. Miny. dan Gas Bumi, vol. 47, no. 2, pp. 97-104, 2013.

20. Hassanshahian M., "Isolation and characterization of biosurfactant producing bacteria from Persian Gulf (Bushehr provenance)," Mar. Pollut. Bull., vol. 86, no. 1-2, pp. 361366, 2014, doi: 10.1016/j.marpolbul.2014.06.043.

21. Yeti D. and N. F. Afianti, "Penerapan dan Tingkat Efektivitas Teknik Bioremediasi untuk Perairan Pantai Tercemar Minyak," vol. XLII, pp. 55-69, 2017.

22. Sen R., Biosurfactants. New York: Landes Bioscience and Springer Science+Business Media, 2010. 